\title{
Tertiary Education for Refugees: A Case Study from the Thai-Burma Border
}

\author{
DunCan MacLaren
}

\begin{abstract}
The Australian Catholic University (ACU) has, since 2003, been involved in providing tertiary education for young refugees who have fled persecution in Burma to end up in refugee camps in Thailand. This paper examines the origins of the program, the changes made as lessons are learned, and the current Diploma program which is also supported by three US universities and York University in Toronto. It also examines how past graduates have used their qualifications for the common good, a term derived from Catholic social thought which informs ACU's specific Catholic identity as a university. The paper further looks at what challenges lie ahead within the Thai-Burmese context and how this model can be replicated in other protracted refugee situations.
\end{abstract}

\section{Résumé}

Depuis 2003, la Australian Catholic University (ACU) fournit un enseignement supérieur à des jeunes qui ont fui la persécution en Birmanie, pour aboutir dans des camps de réfugiés en Thaillande. Cet article examine les origines du programme, les changements apportés au fil de l'expérience et le programme donnant droit à un diplôme, qui est aussi soutenu par trois universités aux É.-U. et par l'Université York, à Toronto. Il examine également de quelles façons les diplômés ont utilisé leurs qualifications pour le bien commun, terme dérivé de la pensée sociale catholique sur laquelle repose l'identité catholique de l'ACU. En outre, cet article examine les défis futurs dans la situation thaï-birmane et en quoi ce modèle de coopération peut être repris dans d'autres situations de déplacement prolongé.

\section{Introduction: The Burmese Background} Causes of Displacement

The latter half of 2010 produced a flurry of publicity on Burma. ${ }^{1}$ So-called democratic elections were held; "The Lady," Aung San Suu Kyi, was released from house arrest; and fighting broke out between a faction of the Democratic Karen Buddhist Army (DKBA) and the Tatmadaw, the junta's military arm, in Myawaddy and surrounding areas at the other end of the Friendship Bridge between Thailand and Burma. The fighting-which still continues-received less publicity than the other events, given the ignorance in international circles of the longest-running civil war in the world between the junta and the various ethnic armies, notably that of the Karen. ${ }^{2}$ Yet this civil war, and the injustices that cause it and flow from it, is the reason that over 150,000 people, mostly from the ethnic minorities of Burma, have fled persecution and poverty in their home villages and towns to go to camps in Thailand.

Loescher et al. claim that the two main causes of forced displacement are the suppression of the pro-democracy movement and the conflict between the junta's military and ethnic military groups. ${ }^{3}$ While that is true, there are other reasons for the displacement. South posits three types of inter-linked displacement crises: type 1, armedconflict displacement; type 2, state/society-induced displacement; and type 3, livelihood/vulnerability-induced displacement. ${ }^{4}$ Examples of the last two types would include corruption, with Burma holding second-last place in Transparency International's Corruption Perceptions Index and its associated costs, both material and human, ${ }^{5}$ endemic poverty, leading to an infant mortality rate of 221 per 1,000 live births in eastern Burma compared to 21 in neighbouring Thailand; ${ }^{6}$ a dearth of honest job opportunities; and a lack of educational opportunities. Overall, Burma/Myanmar ranks 132 out of 169 countries in the UNDP Human Development Index. ${ }^{7}$ Burma's woes stem 
entirely from its government. Burmese historian Thant Myint-U writes,

The Burmese military dictatorship is the longest-lasting military dictatorship in the world, and it is also its purest. It is not an army regime sitting on top of an otherwise civilian state. In Burma by the late 1990s the military was the state. Army officers did everything. Normal government had withered away. ${ }^{8}$

This has been reinforced in the twenty-first century by army officers transmogrifying themselves into "democratically-elected" politicians in the 2010 elections and the beginning of the privatization of state-owned assets, mostly to cronies of the regime.

\section{Higher Education in Burma}

The Burmese government spends 1.3 per cent of gross domestic product (GDP) on education although one international source put the figure for 2010 at 0.9 per cent-an extraordinarily low figure compared even with 2.8 per cent spent on education in East Asia and the Pacific ${ }^{9}$ in general. Less than 60 per cent complete even primary education. ${ }^{10}$ There is a demand for higher education but access to it is controlled by the military. Campuses in Yangon and Mandalay have been moved to the cities' peripheries to avoid demonstrations and the universities are closed on whim. Most students study through "distance learning" so that they do not meet one another, thus ensuring there is no repeat of the student demonstrations of the past. ${ }^{11}$ Strict government control of the Internet largely prevents people from using it as a group-gathering tool, allied with the proven brutality of the regime towards all dissent. The system, such as it is, is shot through with corruption, and jobs for graduates are scarce if they have no link to a member of the military. ACU's students from minority ethnic groups reported discrimination against them in universities, with lecturers even refusing to teach them without a bribe. ${ }^{12}$ Burmese degrees, gained through a rote system of learning in addition to all the other malaises affecting higher education, are seldom recognized internationally. One male law student, quoted in The Irrawaddy, said, "No-one has any respect for Burmese education. Even if you have five degrees in Burma, no-one will care unless you have studied abroad. It's become that bad."13

What follows is the roadmap of an attempt to provide internationally recognized, high-quality tertiary education, at least among young, talented refugees who have fled to camps in Thailand from Burma or who are illegal migrants, recognizing that education is the cornerstone of any democratic society.

\section{Burmese Refugees on the Thai-Burma Border} Education in the Refugee Camps and the Struggle for Tertiary Education

Given the scenario above, described by one commentator as the "Myanmar miasma," it is little wonder that the refugee camps along the Thai side of the border now receive not just the persecuted displaced but also the victims of "educational displacement," children and teenagers sent by their parents because they know the school system is better (as well as gratis) in a refugee camp than in Burma. ${ }^{14}$

In the camps, primary and secondary education is provided by UNHCR and myriad non-governmental organizations (NGOs) specializing in curriculum development, teacher training and provision of materials. In addition, the various ethnic groups have formed their own communitybased organizations (CBOs) which organize the schools, hire teachers, and liaise with international funding and specialist NGOs. Among the Karen, who form around 60 per cent of the refugees overall, it used to be the Karen Education Department (KED), a branch of the governmentin-exile, which had this role. After a clampdown on the more political Karen organizations by the Thai authorities in 2009, a new entity with NGO status - the Karen Refugee Committee-Education Entity (KRC-EE) - was formed to deal with education in the camps, whereas KED now caters for the many Internally Displaced Persons (IDPs) in terms of educational provision within Burma itself.

Camp schools are divided into general primary and secondary schools set up by the camp community and religious schools such as Bible schools and Buddhist monastic schools. Students learn Burmese, English, Maths, Geography, and Health as well as Karen, for that ethnic group, while other ethnic groups establish their own classes to teach their language and culture. There is nowadays a great emphasis on the quality of educational provision as it is generally recognized as being low though better than across the border. ${ }^{15}$

KRC-EE hopes to set up an "Institute of Higher Education," offering a range of specializations geared to "preparing students to serve their communities and fulfilling the needs of the communities both in the camps as well as inside Burma by providing human resources required in different areas," but it requires funding and accreditation which, so far, no university has granted. ${ }^{16}$ In Mae La camp, one hour's drive north of the Thai town of Mae Sot, a college, the Learning and Management Training College (LMTC), has been set up by a number of Karen refugee academics and offers associate BA and BSc degrees, funded by a Swiss NGO, Child's Dream. However, the degrees are not recognized anywhere outside the camphence the use of the term "associate"-despite efforts to secure accreditation from Thai universities. Attempts by 
ZOA Refugee Care, a Dutch NGO, to negotiate with the Royal Thai government to lease land close to Mae La camp for a higher education establishment have foundered on a lack of external funding and Thai prevarication.

The lack of external funding for tertiary education partially stems from the fact that both donor governments and NGOs regard tertiary education as a luxury, preferring to concentrate on the provision of primary and secondary education. This would be acceptable if refugee camps were the temporary phenomena of Fridtjof Nansen's time. It was assumed in the early days of the League of Nations that such refugees were temporary and their status of short-term duration. Two-thirds of all refugees now live in protracted refugee situations (PRS), defined by UNHCR as " 25,000 persons or more who have been in exile for five or more years in developing countries."17 Such situations "involve large refugee populations that are long-standing, chronic or recurring, and for which there are no immediate prospects for a solution,"18 a description that perfectly fits the plight of Burmese refugees in Thailand.

The Thai prevarication flows from historical enmities between the Thais and the Burmese and the desire to avoid more so-called "pull" factors for the Burmese such as tertiary educational provision. ${ }^{19}$ Thailand is not a signatory to the 1951 Refugee Convention and, since the first camp was set up in 1984, has only gradually allowed UNHCR full access, and only since 2005 has permitted resettlement to third countries to take place. In that time, geopolitical relations between the Thai and Burmese governments have also altered. Thailand has become dependent on Burma's vast supplies of natural gas to the extent that approximately 45 per cent of Burma's formal export earnings in 2008 came from Thai gas sales. ${ }^{20}$ A period of "constructive engagement" between the two governments has been ushered in, especially since Burma became a member of the Association of Southeast Asian Nations (ASEAN) in 1997.

The Australian Catholic University (ACU) was the first tertiary institution to offer accredited university education to camp-based refugees on the Thai-Burma border and it continues to do so to this day, albeit in a different form from the past.

\section{ACU Refugee Program on the Thai-Burma Border: Genesis}

Fr. Michael Smith, SJ, former Rector of the Jesuit Theological College in Melbourne, spent some time in refugee camps in the 1980s and in 2000 under the aegis of Jesuit Refugee Service (JRS). ${ }^{21} \mathrm{He}$ witnessed the valiant efforts to educate the children up to secondary level and listened to the frustration of those who were barred from going further. When Fr. Smith returned to Australia, he thought that the difference between dreaming about tertiary education for refugees in the 1980s compared to 2000 was the ubiquitousness of the Internet, making online education a possibility. He formed the Refugee Tertiary Education Committee (RTEC) which included some lecturers from ACU to push this agenda. Eventually, in 2002, through RTEC's advocacy, ACU's Diploma of Business Administration which had been taught successfully online for Aboriginal and Torres Strait Islander students was introduced to the Thai-Burma border. Potential students were interviewed and twenty-one accepted. Students in the pilot program could access ACU's virtual learning environment, WebCT, and took eight business units (courses). Seventeen of the original twenty-one graduated with the Diploma in 2006. An online Certificate in Theology was then offered to students and five graduated in 2009. In early 2008, based on my experience as a former Secretary General of Caritas Internationalis, with a background in humanitarian and development work and as a visiting professor to ACU in 2007, I was appointed coordinator of the program.

\section{ACU Refugee Program on the Thai-Burma Border: A Development Model}

The ACU/RTEC pilot scheme commissioned an evaluation report carried out by Mae Sot-based social anthropologist, Simon Purnell. His methodology comprised focus group discussion to develop an understanding of the course from the students' perspective, a questionnaire using questions provided by ACU, and a further focus group discussion centring on the questions in the questionnaire to develop information from the points raised in the previous two sessions. The report was issued in 2006 and showed that the graduates appreciated three central points in relation to the Diploma in Business-personal self-improvement, provision of skills that would be useful to serve their communities, and the fact that the course was internationally accredited. ${ }^{22}$ The report contained recommendations which were subsequently implemented by the new coordinator. In addition, the coordinator approached the program not just from an educational perspective but also from some basic principles of good development practice, using both secular and Catholic perspectives.

Development, in the words of Amartya Sen, the 1998 Nobel Prize winner in economics, is defined as "a process of expanding the real freedoms that people enjoy." 23 This widens development out of the economic growth model so beloved of government aid departments to encompass social and economic arrangements as well as political and civil rights upon which our freedoms depend. That means removing "unfreedoms" such as poverty or a lack of health 
care or education, one of the constituent components of development. Sen concludes,

With adequate social opportunities, individuals can effectively shape their own destiny and help each other. They need not be seen primarily as passive recipients of the benefits of cunning development programs. There is indeed a strong rationale for recognising the positive role of free and sustainable agency-and even of constructive impatience. ${ }^{24}$

For ACU, as a public university whose philosophy is based on the Catholic intellectual and social tradition, it was important to run a community engagement program which would, in the words of Pope John Paul II's letter on Catholic universities, Ex Corde Ecclesiae,

be capable of searching for ways to make a university education accessible to all those who are able to benefit from it, especially the poor or members of community groups who have customarily been deprived of it. ${ }^{25}$

The program fits perfectly into ACU's mission to be "guided by a fundamental concern for justice and equity and for the dignity of all human beings." 26 The Catholic approach to development-integral human developmentinsists, inter alia, on the poorest having priority and on the participation of the poor themselves in their own development so that they become subjects, not the objects of someone else's idea of how they should be developed. The dignity of the human person has to be promoted at all times and the principle of solidarity demands a commitment to the common good. Pope Benedict XVI describes the common good in the following terms,

[I]t is the good of 'all of us', made up of individuals, families and intermediate groups who together constitute society. It is a good that is sought not for its own sake but for the people who belong to the social community and who can only really and effectively pursue their good within it. To desire the common good and strive towards it is a requirement of justice and charity. ${ }^{27}$

A "commitment to serving the common good" is a desired attribute of all ACU graduates. ${ }^{28}$

Such an approach is a far cry from approaches which result in the experience of a lack of agency that refugees have over their own lives and where dependency becomes the norm in camps.

The combination of following Purnell's recommendations and siting the program firmly within a developmental perspective influenced by Catholic Social Teaching principles has issued in many changes. ${ }^{29}$

\section{Infrastructural and Staff Changes}

The critique in Purnell's evaluation that managerial support, communication with ACU, a resident tutor, and the provision of a safe and stable learning and residential environment were lacking were all addressed. In early 2008, the coordinator undertook, with the local Karen coordinator, to find appropriate accommodation and a study centre in a safe location outside the camp so that Internet could be provided, since it was not permitted by the Thai authorities within the camps. For the first Diploma in Liberal Studies course, a resident volunteer tutor for academic English, motivation, and liaison with online lecturers was appointed in May 2009 in collaboration with the Sydney-based volunteer-sending agency, PALMS. For the second Diploma in Liberal Studies course, a second house was rented so that the sexes could be separated, given the increase in numbers of students. A library is being built up and currently has one thousand titles. There is an adequate number of up-to-date computers; USBs have been provided; the Internet connection has been vastly improved since the early days so that videos can be downloaded.

\section{Diploma in Liberal Studies}

From 2008, following consultations with refugee leaders, NGOs, CBOs, and former students, a wide-ranging Diploma in Liberal Studies was crafted with the aid of four US Jesuit universities which could offer many more online units than could ACU. One of the Jesuit universities has since withdrawn and York University, Toronto, Canada is now participating. The Diploma offered units which adhered to what the refugee community itself regarded as useful. Lecturers progressively changed the content of their units to be of more relevance to the Burmese or refugee context.

The Diploma is taught in mixed mode-online (particularly by the North American universities), face-to-face teaching (by ACU), and specialist tutors who visit to assist students learning new areas of knowledge through an online lecturer. This helps to humanize the program and brings that necessary component of human contact to people who, in many cases, have suffered severe trauma.

\section{Students}

ACU elicited the assistance of some CBOs in identifying potential students who had the commitment to remain on the border. In addition, only students who had been through post-10 secondary education, ${ }^{30}$ had passed a written and oral English test, and had not applied for resettlement at time of application for the course were accepted. In the latest Diploma in Liberal Studies course, the Memorandum of Understanding between ACU and the students asks them to devote at least two years of their time after graduating to 
the refugee or migrant community. This is not enforceable but presents students with a moral commitment.

Whereas all students in the past belonged to the majority ethnic group, the Karen, a deliberate attempt was made to include students of as many ethnic groups as possible. In the current Diploma program, there are eight Burmese ethnicities represented. There was also an attempt to maintain gender equality and, in the current program, there are twenty males and nineteen females following the course.

Since 2009, each Diploma course has begun with an orientation session lasting at least a week on topics such as introducing the participating universities, dealing with expectations of the students as well as the universities' expectation of them, critical thinking, peace-building exercises, and guides to study.

A main task of the resident tutor since 2009 has been to improve on a constant basis students' academic English. To assist this, in 2010, the first unit of the Diploma in Liberal Studies was English Communication Skills, which covered academic English and academic practices such as proper referencing. This will continue in any future course.

Several initiatives have combined to improve feedback to the students of progress (or otherwise) in their work. The overall coordinator, in addition to working on the program on a daily basis, makes two to three trips a year to the study site. The resident tutor is on hand to guide the students on a day-to-day basis and there is a local Burmese coordinator who looks after the students' well-being and security, liaison with the local authorities, and logistical matters. There is increased awareness by the online lecturers of the context in which they work and they use an e-learning system, Blackboard, as well as social networks such as Facebook, to maintain contact with the students. In 2011, ACU's Faculty of Arts and Sciences sent its e-learning manager to coach students in accessing the e-library and to introduce Moodle, as this will be used as the online learning environment by participating universities in future.

One item in the Purnell evaluation which is still workin-progress is assisting the students to find jobs or degree opportunities. Some advances have been made in terms of facilitating access to degree programs and scholarships. One of the graduates of 2010 was successful in securing a place on the Open Universities Australia (OUA) program on the Thai-Burma border, another managed to secure a place in the University of the Sunshine Coast in Queensland, Australia, two have been accepted by ACU, and others are applying to Chiang Mai University and the University of Hong Kong. In addition, discussions have been held with one Thai university about accepting ACU refugee graduates.

\section{ACU Refugee Program on the Thai-Burma Border: Diploma in Liberal Studies 2008-2011}

Following the implementation of the changes delineated above, a Diploma in Liberal Studies with eight units was devised that sought to be more relevant to refugees whether they stayed on the border, were integrated into the host country, repatriated, or resettled in a third country. The first Diploma in Liberal Studies, begun in December 2008, comprised four units from ACU (Business Information Technology, Business Communication Skills, Introduction to International Human Rights Law and Practice, and Managing Organisations, the last two taught in face-toface mode); and one each, all taught online with some tutorial help, from four US Jesuit universities (Leadership Theory, Gonzaga University, Spokane; An Introduction to Anthropology, Saint Louis University; Third World Politics, Fairfield University, Connecticut; and General Psychology, Regis University, Denver). In August 2010, seventeen students graduated in Mae Sot with the dean of the Faculty of Arts and Sciences, Gail Crossley, presiding.

In October 2010, a new Diploma in Liberal Studies was begun with thirty-nine students-thirty in the Mae Sot area and nine in Ranong-with the support of the Marist Fathers. For the first time, Burmese migrants were included as well as refugees. The first unit taught face-to-face by ACU was changed to English Communication Skills in order to familiarize students with academic English and the conventions of academic writing with an emphasis on such matters as proper referencing and avoiding plagiarism. Saint Louis University withdrew from the program and York University in Toronto joined, offering The End of the Earth as We Know it: Global Environmental Change. Fairfield University will offer a course on People, Places and Global Issues. Otherwise, the program remains the same.

\section{Research Findings}

A piece of research undertaken by ACU in 2009 looked at the experience of students who had graduated in business and/or theology to ascertain how their studies had benefited the refugee community if they had remained on the border or the community in diaspora if they had been resettled to a third country. ACU was keen to discover whether the program was producing graduates who, in the words of its graduate attributes, recognized "their responsibility to the common good." 31

The methodology used had to be carefully selected as researching a vulnerable group such as refugees brings its own moral dilemmas. ${ }^{32}$ The refugees on the Thai-Burma border have often been the subjects of research but they have not necessarily seen their lives improved. This has created a mistrust of researchers and so the "hanging out" 
methodology was used in this study. This is the term given by Graeme Rodgers, formerly of the Refugee Studies Centre at Oxford University, to "modest and small-scale qualitative approaches, generated largely through intensive informal and interpersonal interactions between researchers and forced migrants." 33 Pursuing this methodology, a researcher with an in-depth knowledge of the area, culture, language, and most of the students was employed to undertake the interviews, using a flexible questionnaire as a discussion starter.

Since students had been dispersed, only thirteen of the eighteen graduates were able to be contacted. Three had been resettled in either the United States or Australia. All three had managed, on the basis of their ACU qualification, to enter a university to study for a degree with a scholarship. In 2010, one former refugee business student graduated with a Bachelor of Commerce from ACU Melbourne.

For the majority who remained on the border, most worked for CBOs, contributing in myriad ways to the common good. Jobs included managing an orphanage in a refugee camp, providing training for young people in leadership and management, running boarding houses in the camps for unaccompanied minors (part of the educational displacement contingent), working within Burma to document human rights abuses, translating for a resettlement agency, and being employed as a caseworker with an international NGO (INGO). Payment for working in CBOs is more an honorarium than a wage owing to their lack of funding, and so these students who could have opted for resettlement lived up to the ACU graduate attributeswhich stress working for the common good, especially the poor-in spectacular fashion. They also reduced the fears of the refugee leaders that higher education would lead to a hemorrhage of these young people from the camps to the countries of the Global North as their qualifications would hasten their being resettled to the US, Australia, Canada, and elsewhere.

The effect on the students themselves was to give them confidence and make them think critically. One interviewee who worked for an INGO said, "Even though I am not clever, I understand what they [the donors] are talking about and I can stand up and share my opinion now." ${ }^{34}$ Although many foreign NGO and UNHCR workers are empathetic to the refugee community, their work does tend to disempower those they are meant to serve. Some are less empathetic and belong to "a select club in which the rules are set by a rather peculiar set of players who are generally far removed from the realities of the people they purport to help." 35 The ACU qualification enabled the graduates to increase their selfconfidence, resulting in greater autonomy for the refugees.
Since the course was in academic English and used the Internet, all students came out of the process having improved their English speaking and writing skills immeasurably and with an advanced knowledge of e-learning. One student said she would never have been able to keep up with her bachelor's degree program at an American university without the Internet skills and English taught during the Diploma. 36

In addition, the course not only broadened the students' horizons but made them think critically about an armed struggle they had been taught to accept as a matter of course. A Burmese teacher said that, in the past, post-secondary school students would happily "carry the gun and go directly to the front line and become an officer there-that's the only thing we can do." ${ }^{37}$ The course, which included peace-building exercises, made the graduates question established and largely utopian ideas of the political future and they began to promote political negotiation rather than war as a possible solution. One student commented, "when democracy comes to Burma, we will be prepared." ${ }^{8}$

\section{ACU Refugee Program: Ramifications and Prospects}

The program was awarded Best Collaborative International Project at the prestigious Australian Business Higher Education Round Table Awards (B-Hert) in 2008 and gained the ACU Vice-Chancellor's Award for Outstanding Community Engagement in 2010. More importantly, it is a program that has fired the imagination of other universities which are now considering tertiary education for refugees. Perhaps one of the most advanced is the initiative Jesuit Commons: Higher Education at the Margins (JC-HEM), which seeks to link Jesuit Refugee Service (JRS) and Jesuit universities worldwide in an effort to provide tertiary education to refugees in three pilot schemes in camps in Malawi, Kenya, and Syria. The JC-HEM International Director was involved in and influenced by the ACU program on the Thai-Burma border. The program began in 2011.

There are certain elements of the ACU program which could be replicated in similar programs in other refugee situations. They include looking at the situation through not just an educational lens but a developmental one, the necessity of providing the right infrastructure, the importance of participation by the refugee community in the choice of units, and the employment of a local coordinator for security and logistics as well as a tutor for academic English and liaison with online lecturers. A sine qua non is an ongoing financial commitment by participating universities to the refugee community as an ethical imperative. However, the Thai-Burma situation also has unique factors. Apart from the fact that Thailand is not a signatory to the 1951 Refugee 
Convention, there are many risks associated with the political turmoil in Thailand itself, the relationship between Thailand and the junta in Burma, and the fighting in the border region of Burma which has implications for the other side of the Moei River in Thailand. In January 2011, nearly 10,000 civilians displaced by the fighting in Karen State were hiding on the Thai side of the border and being assisted by local communities and NGOs. They had not gone to official camps as they had already been sent back to Burma several times by the Thai authorities following previous displacement by conflict. ${ }^{39}$ This could be a precursor of things to come.

The program has been successful because ACU and its partners, both other universities and local partners and staff, have been committed to it in terms of finance, staff, and determination. The future will require institutional funding as well as new ideas to combat obstacles put in the program's way. Perhaps its most profound value lies in illustrating that tertiary education, which in the past has been regarded by UNHCR and NGOs as a luxury for refugees in temporary situations, is now recognized in fact as a right for those caught particularly in protracted situations and that it can have wide ramifications for individual refugees, the refugee community, and the general common good.

In the words of Tomás Ojea Quintana, the UN’s special rapporteur on human rights in Myanmar, "Education is both a human right in itself and an indispensable means of realising other human rights." ${ }^{20}$ In the camps, tertiary education will not only supply intellectual capital which has largely been lost in the resettlement process, as well as providing the community which remains with teachers, social workers, and above all community leaders, but it will be an enabling right which could lead to real improvements for the refugee community in relation to the Royal Thai government, UNHCR, and NGOs. Tertiary education will restore to refugees more agency over their own lives. In a limited but important way, ACU's tertiary education program contributes not only to education and human rights, but to the dignity of an entire marginalized community.

\section{Appendix}

Abbreviations used in the text

ACU Australian Catholic University

ASEAN Association of Southeast Asian Nations

BPHWT Back Packer Health Worker Team

CBO Community-based organisation

DKBA Democratic Karen Buddhist Army

IDP Internally Displaced Person

INGO International Non-governmental Organisation

JC-HEM Jesuit Commons: Higher Education at the Margins

JRS Jesuit Refugee Service
KED Karen Education Department

KRC-EE Karen Refugee Committee-Education Entity

LMTC Learning and Management Training College

NGO Non-governmental organisation

OUA Open Universities Australia

RTEC Refugee Tertiary Education Committee

UNDP United Nations Development Program

UNHCR Office of the High Commissioner for Refugees

WebCT Web Course Tools or the Blackboard Learning System

\section{Notes}

1. I use "Burma" in preference to "Myanmar," the name imposed on the country by the ruling junta in 1989. "Myanmar" is taken from the literary form of Burmese while "Burma" is derived from the spoken, more demotic form. This is in line with the generals' view that they are the successors of the warrior kings of old Myanmar. By using "Burma," I follow the convention used by Australia and Canada, "realists" as opposed to "nominalists" in the political game surrounding the name of the country after the 1988 coup. See Lowell Dittmer, "Burma vs. Myanmar: What's in a Name," Asian Survey 48, no. 6 (November/ December 2008): 885-88.

2. For information on the Karen, see Phil Thornton, Restless Souls: Rebels, Refugees, Medics and Misfits on the ThaiBurma Border (Bangkok: Asia Books, 2006).

3. Gil Loescher, James Milner, Edward Newman, and Gary Troeller, eds., Protracted Refugee Situations: Political, Human Rights and Security Implications (Tokyo: United Nations University Press, 2008), 304-05.

4. Ashley South, "Burma: The Changing Nature of Displacement Crises" (Working Paper No. 39, Refugee Studies Centre, University of Oxford, 2007).

5. It is ranked 176th along with Afghanistan. At the bottom, at 178 th, is the failed state of Somalia. See Transparency International, Corruption Perceptions Index 2010, accessed 20 January 2011, http//www.transparency.org/ policy_research/surveys_indices/cpi.

6. David I. Steinberg, Burma/Myanmar: What Everyone Needs to Know (Oxford: Oxford University Press, 2010), 97.

7. UNDP Human Development Index, accessed 20 January 2011, http://hdr.undp.org/en/.

8. Thant Myint-U, The River of Lost Footsteps: A Personal History of Burma (New York: Faber and Faber, 2007), 340.

9. United Nations Human Rights Council (7th March 2011), Progress Report of the Special Rapporteur on the situation of human rights in Myanmar, Tomás Ojea Quintana, UN General Assembly GE, 11-11577, 12.

10. Ibid., 13.

11. "Burma's Public Education Crisis," The Irrawaddy, 17 March 2011, accessed 11 June 2011, http://www.irrawaddy .org.print_article.php/art_id=20954; also Steinberg, Burma/ Myanmar: What Everyone Needs to Know, 68. 
12. Private conversations with students of various ethnic backgrounds, Mae Sot, 2008-10.

13. "Burma's Public Education Crisis."

14. Steinberg, Burma/Myanmar: What Everyone Needs to Know, xxviv.

15. Simon Purnell with Aranya Kengkunchorn, "Taking Learning Further: A Research Paper on Refugee Access to Higher Education (Mae Sot: ZOA Refugee Care, 2008), 16-17.

16. Niamh de Loughry, "Tertiary Education for Refugees in Pursuit of the Common Good: the Thai-Burma Border Experience" (unpublished report for ACU, 2009), 6.

17. Gil Loescher and James Milner, "Understanding the Problem of PRS," in Protracted Refugee Situations, ed. Loescher, Milner, Newman, and Troeller, 21.

18. Ibid., 23.

19. For example, in 1767 , the Burmese sacked the ancient capital of Siam, Ayutthaya.

20. Sean Turnell, "Burma's Poverty of Riches: Natural Gas and the Voracious State," in Burma or Myanmar: The Struggle for National Identity, ed. Lowell Dittmer (Hackensack, NJ: World Scientific Books 2010), 209.

21. See Susan Costello, Marie Joyce, Michael Smith, Duncan MacLaren, and Thein Naing, "Bringing Higher Education to Displaced Burmese Minorities in International Advances in Education: Global Initiatives for Equity and Social Justice," in Ethnicity and Race, vol. 2, ed. Elinor L. Brown, Ekaterina V. Dvoretskaya, and Pamela Gibbons (Charlotte, NC: Information Age Publishing, forthcoming in late 2011).

22. Simon Purnell, "ACU/RTEC Evaluation Report" (January 2006; unpublished).

23. Amartya Sen, Development as Freedom, (Oxford: Oxford University Press, 1999), 3ff.

24. Ibid., 11.

25. Pope John Paul II, Ex Corde Ecclesiae (Libreria Editrice Vaticana 1990), par 34.

26. ACU Handbook 2011, 3.

27. Pope Benedict XVI, Caritas in Veritate [Charity in Truth] (Vatican City: Editrice Vaticana, 2009), par. 7.

28. ACU Handbook 2011, 3.

29. See Duncan MacLaren, Jamie Davies, Br. Laurie Needham, and Anthony Steel, Principles of Engagement on International Development Through the Lens of Catholic Social Teaching (Sydney: ACU, Caritas Australia and Catholic Religious Australia, 2010).
30. Post-10 schools provide extra training after secondary education is completed. They provide a range of subjects including social studies, Thai, leadership training, and Burmese but all of them teach in English. See Purnell with Kengkunchorn, “Taking Learning Further," 17.

31. ACU, Graduate Attributes, 2009, http://www.acu.edu.au/ student_resources/study_resources/graduate_attributes/.

32. Catriona MacKenzie, Christopher McDowell, and Eileen Pittaway, "Beyond 'Do No Harm': The Challenge of Constructing Ethical Relationships in Refugee Research," Journal of Refugee Studies 20, no. 2 (June 2007): 299-319.

33. Graeme Rodgers, "Hanging Out' with Forced Migrants: Methodological and Ethical Challenges," Forced Migration Review 21 (September 2004): 48-49.

34. Niamh de Loughry, unpublished interview notes, 2009. For a fuller presentation on this aspect, see Duncan MacLaren, "Tertiary Education in Pursuit of the Common Good: The Thai-Burma Border Experience," in Learning, Teaching and Social Justice in Higher Education, Noah Riseman, Sue Rechter, and Ellen Warne, eds. (Melbourne: University of Melbourne eScholarship Research Centre, 2010), 111-23.

35. Antonio Donini, Looking Ahead: Making our Principles Work in the Real World (Boston: Tufts University, Feinstein International Center, 2007), 2.

36. Niamh de Loughry, unpublished interview notes.

37. Ibid.

38. Ibid.

39. Situation update email from the Back Packer Health Worker Team (BPHWT), received 21 January 2011.

40. United Nations Human Rights Council (7th March 2011) Progress Report of the Special Rapporteur on the situation of human rights in Myanmar, Tomás Ojea Quintana, UN General Assembly GE. 11-11577. 12.

Duncan MacLaren, former secretary general of Caritas Internationalis, lectures at the North Sydney campus of Australian Catholic University (ACU) and coordinates ACU'S refugee program on the Thai-Burma border and the new Bachelor of International Development Studies degree. He holds degrees in languages, theology, and development studies from the Universities of Glasgow and Edinburgh and has lectured widely on development issues, NGOs, and Catholic social teaching. 